\title{
State and prospects of state regulation of markets of addictive goods in Russia
}

\author{
Skokov Roman Yurievich \\ Federal State Budgetary Educational Institution of Higher Education \\ "Volgograd State Agricultural University" \\ city of Volgograd, Russia \\ rskokov@mail.ru
}

\begin{abstract}
The aim of the article is to develop socially and economically expedient forms of functioning of regulated markets of addictive goods in Russia. The study is based on systemic-evolutionary, dialectical, and institutional approaches. The main scientific problem raised in the article is at the junction of studies of "free markets" and markets with government regulatory initiatives. The novelty consists in the argument of the preference of the state monopoly, which theoretically reduces the supply, price increases, reducing the impact of the motive of private profit, and, in practice - the reduction of the shadow sector, the growth of budget revenues and the ability to connect the fiscal and social interests of the state more effectively. The article presents an analysis of the types of markets of the main addictive goods in international practice, the periodization of the public administration system with the help of representative market of alcoholic beverages and their evaluation, the actual competitive characteristics of domestic markets, scenarios of institutional regulation and evaluation of the effectiveness of state instruments in scenario conditions. The field of institutional changes in the domestic markets of addictive goods is defined within the inertial, modernizational, state-monopoly and prohibitionists' scenarios. The greatest integral efficiency of measures of state regulation of the markets of addictive goods (taxation, pricing, rationing of places, time and days of trade, etc.) in the conditions of state monopoly is reasoned.
\end{abstract}

Keywords - addictive goods, alcohol products, tobacco products, drugs, gambling games, competition, state monopoly

\section{INTRODUCTION}

In intellectual battles in political economy, with the growing influence of faith in free markets and minimal state, it is necessary to include research into special markets for addictive goods that are pathological and play a crucial role in the social and economic life of society. The object of consideration in this article are such addictive products as alcohol and alcohol-containing products, tobacco products and electronic cigarettes, energy drinks, drugs, gambling. In the markets of addictive goods there is a "rejection" of the market mechanism, which requires state intervention. The level of restrictive state regulation shows that the expansion of the system of objects and subjects, methods and tools, forms and terms, sources and channels of restrictions in the regulation of markets of addictive goods can be arbitrarily large. Therefore, there is a problem of choosing the most effective tools to achieve the purpose of the regulator.

\section{RESEARCH METHODS}

The research is based on the works of Russian and foreign scientists in the field of the general economic theory, institutional and evolutionary economics, as well as private theories of patronized goods and specific markets, efficiency of production and public administration, the shadow economy, the economy of crime. The methods of expert estimation, analysis, synthesis, analogy, comparison, monographic, historical and logical, typologization, scenario forecasting were used in the course of the research.

\section{PROBLEM STATEMENT}

The functioning of the markets of addictive goods is accompanied by a wide range of effects for the state, society, business, consumers. The plurality of interests of the parties and the plurality of balances in the market system of addictive goods correspond to the plurality of parameters of institutions that are formed in society to solve social, economic, political and other problems. Arising contradictions, low socioeconomic efficiency of self-regulation actualize modification, transformation, elimination or creation of the mechanism of institutional regulation of markets of additive goods.

\section{RESEARCH QUESTIONS}

The study answers the following questions: what is the current competitive state of the domestic markets of addictive goods; what are the basic models of market regulation of addictive goods are common in international practice; what is the difference in state regulation of markets for addictive goods in Russia; what is the domestic experience of realization of different public management systems markets for addictive goods; what are the prospects of government regulation of markets of addictive goods; what is the effectiveness of state instruments in the conditions of competition, modernization, state monopoly, prohibition.

\section{PuRPose OF THE STUdY}

The aim of the study is to develop socially and economically advisable forms of functioning of regulated markets of addictive goods in Russia. 


\section{RESULTS AND DISCUSSION}

\section{A. The state of the markets of the main addictive goods in Russia}

In Russia 45.9 million of the adult population consume alcohol, 37.6 million - tobacco, approximately 29 million energy drinks, 7.3 million - drugs. The functioning of the markets of addictive goods is accompanied by a wide range of effects for the state, society, business, consumers. In 2016, on the one hand, the Russian budget received excise taxes from tobacco products of 466.9 billion rubles, from strong alcoholic beverages -164.2 billion rubles, from beer -148.3 billion rubles. On the other hand, mortality caused by alcohol-related etiology accounts for 56.3 thousand people in 2016, by drugs 90 thousand people, smoking - 330-400 thousand people. The number of crimes committed by persons in a condition of alcoholic intoxication is 440.2 million in 2016 . The proportion of crimes in a condition of alcoholic, narcotic and toxic substances in the overall number of crimes increased from $8.7 \%$ in the period of 2007-2011 to $17.8 \%$ in 2012-2016.

The complete prohibition or legalization of markets for addictive goods is as abstract as the achievement of perfect competition or the establishment of a pure monopoly. In reality, the institutional regulation of the markets of addictive goods is based on various combinations of prohibition and liberalism, monopoly and competition, which should serve to achieve an effective balance of interests of the state and society, the consumer and the producer. The search for such balance reflects the characteristics of the domestic markets of the main addictive goods in table 01 .

The market of alcohol and alcohol-containing products regulated by the state is a market of monopolistic competition. The specifics of competitive conditions in the state-regulated market of tobacco products and the market of energy drinks can be attributed to oligopolistic. Limited by government, markets of gambling games within the borders of the five selected gambling zones in Russia and licensed games in bookmaker offices and the totes are regulated by oligopolies. The organization of lotteries in Russia is a state monopoly.

TABLE I. COMPETITIVE CHARACTERISTICS OF THE MARKETS OF ADDICTIVE GOODS IN RUSSIA (2015-2017)

\begin{tabular}{|c|c|c|c|c|c|c|}
\hline Indicators & Marks of competition and monopoly & \\
\hline $\begin{array}{c}\text { Number of } \\
\text { manufacturers. }\end{array}$ & Variet. & Restr. & Restr. & Restr. & Restr. \\
\hline $\begin{array}{c}\text { Number of } \\
\text { consumers. }\end{array}$ & Variet. & Variet. & Variet. & Variet. & Variet. \\
\hline $\begin{array}{c}\text { Product } \\
\text { differentiation. }\end{array}$ & + & + & + & + & + \\
\hline $\begin{array}{c}\text { Competitive } \\
\text { pricing. }\end{array}$ & + & - & + & + & - \\
\hline $\begin{array}{c}\text { The difficulty of } \\
\text { access to } \\
\text { competitors. }\end{array}$ & - & + & + & - & + \\
\hline
\end{tabular}

\begin{tabular}{|c|c|c|c|c|c|}
\hline $\begin{array}{c}\text { Signs of unfair } \\
\text { competition. }\end{array}$ & + & + & + & + & + \\
\hline $\begin{array}{c}\text { Signs of } \\
\text { monopolistic } \\
\text { activity. }\end{array}$ & + & + & - & + & + \\
\hline \multicolumn{6}{|c|}{ Imperatives and priorities of government influence } \\
\hline $\begin{array}{c}\text { Imperatives of } \\
\text { public bodies: }\end{array}$ & + & - & - & + & + \\
\hline $\begin{array}{c}\text { restriction of } \\
\text { entry into the } \\
\text { market of firms; }\end{array}$ & + & + & - & + & + \\
\hline $\begin{array}{c}- \text { conditions of } \\
\text { production and } \\
\text { exchange; }\end{array}$ & + & + & - & + & + \\
\hline $\begin{array}{c}\text { consumption } \\
\text { conditions. }\end{array}$ & + & + & - & - & - \\
\hline $\begin{array}{c}\text { State and } \\
\text { municipal } \\
\text { preferences }\end{array}$ & + & - & & & \\
\hline
\end{tabular}

Access to the market of gambling games in bookmaker offices and totes is almost unlimited by competitors. With the weakening of state requirements, it is potentially competitive. The drug market operates in terms of combination of: a) official government prohibition; b) strict government monopoly on the cultivation of narcotic plants for use in scientific, educational purposes, in expert and some other legitimate activities; c) the shadow monopoly structures in the form of cartels, syndicates or multifunctional OPG.

\section{B. Forms of functioning of the markets of addictive goods in international practice.}

The prevailing market conditions of the main addictive products in international practice are systematized in table 02 .

They are represented by a state monopoly in one form or another (SM), by market competition with the licensing requirements or otherwise to organizations of all patterns of ownership (CM), by prohibition (PM); by the medical (MM) system, by the antiprohibition moderately liberal (MLM) system, by the hybrid (HM) system. 
TABLE II. TYPES OF MARKETS OF THE MAIN ADDICTIVE GOODS IN INTERNATIONAL PRACTICE

\begin{tabular}{|c|c|c|}
\hline Product & $\begin{array}{l}\text { Type of } \\
\text { market }\end{array}$ & Country localization \\
\hline \multirow{3}{*}{$\begin{array}{l}\text { Alcoholic and } \\
\text { alcohol- } \\
\text { containing } \\
\text { products }\end{array}$} & SM & $\begin{array}{c}\text { Finland, Norway, Sweden, Iceland, Faroe } \\
\text { Islands, Latvia, Belarus, Bulgaria, Canada, } \\
\text { France, Germany, Switzerland, } \\
\text { Macedonia, Turkey, Turkmenistan, in a } \\
\text { number of States of the USA and India, } \\
\text { Uruguay. }\end{array}$ \\
\hline & $\mathrm{CM}$ & $\begin{array}{l}\text { Russia, France, Portugal, Austria, Estonia, } \\
\text { Italy, Poland, United Kingdom, Spain, } \\
\text { Greece, Hungary, Slovakia, Czech } \\
\text { Republic, Slovenia. }\end{array}$ \\
\hline & PM & $\begin{array}{l}\text { UAE, Saudi Arabia, Iran, Bangladesh, } \\
\text { Pakistan, Libya, Yemen, Kuwait, } \\
\text { Afghanistan, Sudan. }\end{array}$ \\
\hline \multirow{2}{*}{$\begin{array}{l}\text { Tobacco } \\
\text { product }\end{array}$} & $\mathrm{CM}$ & Russia and most countries of the world. \\
\hline & SM & $\begin{array}{l}\text { France, Hungary, Austria, China, Italy, } \\
\text { Turkey, Germany, Iceland. }\end{array}$ \\
\hline \multirow{3}{*}{ Energy drinks } & $\mathrm{CM}$ & $\begin{array}{l}\text { Russia, the US and the UK, Latvia, } \\
\text { Germany and Taiwan (ban sales Red Bull } \\
\text { Cola), Sweden (ban sales for children } \\
\text { under } 15 \text { years). }\end{array}$ \\
\hline & MM & $\begin{array}{c}\text { Denmark, France, Norway, Kazakhstan } \\
\text { (draft). }\end{array}$ \\
\hline & PM & $\begin{array}{l}\text { Uruguay, Turkmenistan, Africa, new } \\
\text { Zealand, Australia, the Chechen Republic } \\
\text { (Russia). }\end{array}$ \\
\hline \multirow[b]{2}{*}{ Drugs } & $\begin{array}{l}\text { PM, SM, } \\
\text { MM }\end{array}$ & Russia and most countries of the world. \\
\hline & MLM & $\begin{array}{l}\text { Holland, Germany, Australia, Argentina, } \\
\text { Belgium, Canada, United Kingdom, } \\
\text { Mexico, some US States, Czech Republic, } \\
\text { Switzerland, Luxembourg, Spain, } \\
\text { Portugal, Jamaica, Israel. }\end{array}$ \\
\hline \multicolumn{3}{|l|}{$\begin{array}{l}\text { Gambling } \\
\text { games: }\end{array}$} \\
\hline \multirow[b]{4}{*}{$\begin{array}{l}\text { casinos and } \\
\text { other gambling } \\
\text { establishments }\end{array}$} & $\mathrm{CM}$ & USA, Switzerland, France, UK. \\
\hline & $\mathrm{HM}$ & $\begin{array}{l}\text { Italy. } \\
\end{array}$ \\
\hline & SM & Finland, Hungary, Philippines. \\
\hline & PM & $\begin{array}{l}\text { Russia, The Border, Denmark, Israel, } \\
\text { Ireland, Average, Yemen, Cambodia, } \\
\text { China, Libya, Liechtenstein, Mexico, } \\
\text { Norway, Saudi Arabia, Turkey, } \\
\text { Azerbaijan, Turkmenistan, Tajikistan, } \\
\text { Kyrgyzstan. } \\
\end{array}$ \\
\hline \multirow{3}{*}{$\begin{array}{l}\text { betting offices, } \\
\text { totes }\end{array}$} & $\mathrm{CM}$ & $\begin{array}{l}\text { Russia, Italy, France. } \\
\end{array}$ \\
\hline & SM & Germany, Sweden. \\
\hline & PM & $\begin{array}{l}\text { Kyrgyzstan, Kuwait, Bahrain, Qatar, } \\
\text { Oman, Yemen, Iran, Saudi Arabia, } \\
\text { Turkey, Libya. }\end{array}$ \\
\hline \multirow[t]{2}{*}{ - lottery } & SM & $\begin{array}{c}\text { Russia, Austria, Belgium, Bosnia and } \\
\text { Herzegovina, Hungary, Latvia, Lithuania, } \\
\text { Luxembourg, Malta, Norway, Poland, } \\
\text { Portugal, Croatia, Czech Republic, } \\
\text { Finland, France, Bulgaria, Greece, Spain, } \\
\text { Italy, Ireland, Ukraine, Sweden, } \\
\text { Switzerland, Germany, great Britain, } \\
\text { Turkey, Singapore, Argentina, Japan, } \\
\text { China, Malaysia, Israel, Mexico, USA, } \\
\text { Canada, Australia, Georgia. } \\
\end{array}$ \\
\hline & PM & $\begin{array}{l}\text { Kuwait, Bahrain, Oman, Qatar, Iran, Saudi } \\
\text { Arabia, Libya, Turkey, Yemen. }\end{array}$ \\
\hline
\end{tabular}

State regulation of the markets of addictive goods in Russia is different from the world practice: in the market of alcoholic beverages there is a competitive licensing system of state regulation, but in close to the stereotype of consumption countries there is a state monopoly. The potential of state regulation of the demand for tobacco products is not implemented; electronic cigarettes and energy drinks are not involved in the economic potential of the markets; drugs are not allowed; barriers to the development of gambling markets and new addictive products (dry alcohol, Internet gambling) are being created.

\section{State monopoly on the markets of addictive goods in economic theory and in Russian practice.}

From the point of view of economic theory, the state monopoly on addictive goods on the one hand (social) will help reduce the volume of supply, establish higher prices, reduce the impact of the motive of private profit, which is appropriate in this area; on the other hand (economic), it will help reduce the shadow sector, increase budget revenues. In different periods P. Berg (Frånberg, 1987), J. Buchanan (Buchanan, 1980), S. Witte (Witte, 2015, p.235), A. Zhuk and E. Kizilova (Zhuk, Kizilova, 2014), Y. Latov and S. Kovalev (Latov, Kovalev, 2006, p.235), D. Mendeleev (Khodorkov, 2005, p.717-718), M. Olson (Olson, 1995, p.55-56), John Ornberg and H. Oulavsdouttir (Örnberg, ÓlafsdÓttir, 2008), R. Room (Room, 1993), N. Rehn and G. Edwards (Rehn, Room, Edwards, 2001), L. Timofeev (Timofeev, 2001, p.253), D. Khalturina and A. Korotaev (Khalturina, Korotaev, 2006), T. Schelling (1967, p.717-718) spoke with the argumentation of these premises.

In the Russian practice, the state monopoly (1474-1553, 1651-1663, 1681-1705, 1819-1826, 1895-1913, 1923-1984, 1989-1991) showed greater socio-economic efficiency compared to other forms: sale of drinks for the faith (1590$1650)$; the farming system or public-private partnership (1765$1818,1824-1862)$; mixed (1554-1589, 1664-1680, 17061764); prohibition (1914-1922, 1985-1988); the competitive model with licensing and excise taxation (1863-1894, 19922018), including the model with elements of public-private partnership in 2008-2015.

In 1895-1913, the state monopolization of the retail sale of alcoholic beverages in Russia demonstrated the ability to effectively combine the fiscal interest of the state and public health care. A whole industry was created, including 336 vodka factories, which employed more than 60 thousand people; drink revenues increased 3.5 times in 1913 compared with 1890 (from 268.3 million rubles to 953 million rubles) (Rozhkov, 2007), accounting for about $26 \%$ of the revenue of the state. The quality of products improved, negative consequences of consumption decreased. The level of consumption of alcoholic beverages at the beginning of the excise system in 1863 amounted to 14.76 liters of pure alcohol per capita per year, and after the introduction of the wine monopoly in 1913 - 3.6 liters (Bykova, 2012).

Empirical studies in 1960-2017 showed that the level of shadow activity in the market of strong alcoholic beverages was the lowest during the periods when the state monopoly on 
production, turnover and retail trade of alcoholic beverages (1960-1984 and 1989-1991), except for alcohol reform in the years of perestroika (1985-1988). During the Soviet period, the level of shadow activity in the market of strong alcoholic beverages was practically absent. In the total amount of open budget revenues, the share of alcoholic beverages in 1970 and 1980 accounted for $6.5 \%$. The level of fatal poisoning by illegal alcoholic beverages and surrogates in 1970, 1975 and 1980 respectively amounted to 19 thousand people, 23 thousand people and 32 thousand people.

In the institutional structure of the market of alcohol and alcohol-containing products in 2016 , the share of legal activity is $31 \%$. The decrease in the level of shadow activity will contribute to an increase in tax revenues and fees, improve the efficiency of legal market participants, reduce the number of offenses in the alcohol sector, reduce the disparity in prices for legal and illegal products.

\section{Scenarios of institutional regulation of the markets of addictive goods.}

Analysis of domestic and global trends in the development of institutional regulation of national markets of addictive goods allow us to synthesize alternative scenarios in the future implementation of these processes in Russia, which express a certain level of restriction in the mechanism of market regulation through the attitude of the policy of full prohibition to the policy of full liberalism (Skokov, 2014).

A (inertial scenario). It is aimed at preserving, maintaining and strengthening existing institutions and regulatory mechanisms. It presupposes preservation of the existing unstable structure of the markets of addictive goods, with the existing mechanism of state regulation and its fundamental shortcomings.

B (the modernization scenario). It involves the modernization of institutions, the implementation of a set of measures to reduce the burden of the negative consequences associated with the consumption of addictive goods and the adequate use of socio-economic potential of industries. It provides for the creation of a contractual system of publicprivate partnership in the field of production, circulation, distribution of addictive goods, as well as the implementation of a set of measures to regulate their markets: increasing the role of authorities in the field of health and social protection of the population in the formulation of policy; development of the Concept of the state policy of reducing the consumption of addictive goods and prevention of addictions; institutionalization of lobbying; separate state regulation of specific markets of alcoholic beverages; new ways of operational control of product quality, identification of its authenticity and properties; stimulation of self-regulation and voluntary institutional initiatives, etc.

C (state monopoly scenario). It involves the creation, functioning of new institutions and the implementation of a set of measures in the context of the introduction of a state monopoly on the retail sale of addictive products.
D (Prohibition scenario). It is a total ban on the production, supply and consumption, for non-medical purposes, of any addictive goods.

At the present stage, the government is implementing a plan of monopolization of the alcohol industry (economic factor) on the market of alcohol and alcohol-containing products. The lobbying efforts of transnational tobacco companies and energy producers are opposed by strong economic and administrative measures aimed at reducing the consumption of tobacco products and energy drinks (a social factor). The gambling market also becomes an object of attention of the state from the point of view of replenishment of the budget by opening of additional gambling zones (economic factor). The international experience of drug legalization is categorically not supported by the Russian public and authorities; therefore, inertial development will remain here (social and political factor).

\section{E. The effectiveness of traditional instruments of state regulation in various scenario conditions.}

It is important to consider trends and patterns of influence of state regulation tools on demand and supply of addictive goods in certain scenario conditions. Table 3 presents a rating of the effectiveness of traditional measures of state regulation in the conditions of the scenarios. The highest rating of efficiency of measures within the framework of a scenario is marked by one; the lowest is marked by four.

TABLE III. RATING OF THE EFFECTIVENESS OF THE MEASURES OF THE INSTITUTIONAL PROJECT IN THE MARKETS OF ADDICTIVE GOODS

\begin{tabular}{|l|c|c|c|c|}
\hline \multirow{2}{*}{ Measures of institutional projection } & \multicolumn{4}{c|}{ Scenarios } \\
\cline { 2 - 6 } & A & B & C & D \\
\hline $\begin{array}{l}\text { 1. Reduction of shadow economic activity, sale } \\
\text { of products of domestic production, surrogates. }\end{array}$ & 4 & 2 & 1 & 3 \\
\hline 2. Economic availability. & & & & \\
\hline 2.1. Taxation. & 3 & 2 & 1 & - \\
\hline 2.2. Price regulation. & 3 & 2 & 1 & - \\
\hline 3. Physical availability. & & & & \\
\hline $\begin{array}{l}\text { 3.1. The number, density and type of outlets, the } \\
\text { availability of individual addictive products. }\end{array}$ & 4 & 3 & 1 & 2 \\
\hline $\begin{array}{l}\text { 3.2. Limitation of time and days of sale of } \\
\text { addictive products. }\end{array}$ & 4 & 3 & 1 & 2 \\
\hline $\begin{array}{l}\text { 3.3. The minimum age limit for the purchase or } \\
\text { consumption of addictive goods. }\end{array}$ & 3 & 2 & 1 & 4 \\
\hline $\begin{array}{l}\text { 4. Restrictions on sales promotion (advertising, } \\
\text { sponsorship, marketing). }\end{array}$ & 4 & 3 & 2 & 1 \\
\hline $\begin{array}{l}\text { 5. Influence on addictive consumer behavior in } \\
\text { risky environments. }\end{array}$ & 3 & 2 & 1 & 3 \\
\hline $\begin{array}{l}\text { 6. Prevention, diagnosis, reduction of negative } \\
\text { consequences of addictive consumer behavior. }\end{array}$ & 3 & 2 & 1 & 2 \\
\hline
\end{tabular}

In the analyzed scenarios, the greatest efficiency of concrete measures in the public interest will be achieved by monopolization of retail trade of addictive goods.

\section{FINDINGS}

Based on the assessment of the development and state of society in Russia, the theory and practice of regulation at the present stage in the markets of addictive goods, the state 
monopoly is the most acceptable. Its advantage is that it allows one to reduce supply, increase prices, reduce private interest in increasing sales and profits, reduce the shadow sector, increase budget revenues, standardizes and unifies physical and economic availability, has proved its effectiveness in domestic practice and in experience of countries close to the consumption stereotype of Russia.

\section{Acknowledgment}

For invaluable assistance in the preparation of the study, I am grateful to my supervisor, doctor of Economics, Professor Oleg V. Inshakov (30.06.1952-06.01.2018).

\section{References}

[1] P. Frånberg, "The Swedish Snaps: A History of Booze, Bratt and Bureaucracy -- a summary. Contemporary Drug Problems", vol. 14, pp. 557-611, $1987 . \quad$ Retrieved from http://heinonline.org/HOL/LandingPage?handle=hein.journals/condp14 $\&$ div $=35 \&$ id $=\&$ page $=$

[2] J. M. Buchanan, "A Defence of Organized Crime? Retrieved from", 1980.

https://sorbonne.pierrekopp.com/downloads/1974\%20BUCHANAN\%20 A\%20defense\%20of\%20organized\%20crime.pdf

[3] S. Yu. Witte, Summary of lectures on the national and state economy, read his Imperial Highness Grand Duke Mikhail Alexandrovich in the years 1900-1902. Moscow: Yurayt, 2015.

[4] A. A. Zhuk, E. A. Kizilova, "Mechanisms of state regulation of the alcohol market in the countries of the Eurasian region", Regional Economics: theory and practice, vol. 13, pp. 49-59, 2014. Retrieved from http://cyberleninka.ru/article/n/mehanizmy-gosudarstvennogoregulirovaniya-rynka-alkogolnoy-produktsii-v-stranah-evraziyskogometaregona

[5] Yu. V. Latov, S. N. Kovalev, Shadow economy. Moscow: Norma, 2006.

[6] A. G. Khodorkov, World economic thought. Through the prism of centuries. The era of social fractures. Moscow: Thought, 2005.
[7] M. Olson, "The dispersion of power and society in transition period. The cure for corruption, disintegration and economic slowdown", Economics and mathematical methods, vol. 31, pp. 55-56, 1995.

[8] J. Örnberg, H.ÓlafsdÓttir, "How to sell alcohol? Nordic alcohol monopolies in a changing epoch", vol. 25, pp. 129-153, 2008. Retrieved from http://www.nopus.org/PageFiles/4589/CisnerosOlafsdottir.pdf

[9] R. Room "The evolution of alcohol monopolies and their relevance for public health". $\quad$ Retrieved from, 1993. http://www.robinroom.net/evolutio.htm\#N_1_

[10] N. Rehn, R.Room, G. Edwards, "Alcohol consumption, harm and policy in the WHO - European region". Retrieved from, 2001 http://www.euro.who.int/docement/e76240r.pdf

[11] L.E. Keselman, M.G.Matskevich, L.M. Timofeev, "Social space of drug use. Drug business". The initial theory of economic industry. SPb. Medical press, 2001.

[12] D. A. Khalturina, A. V. Korotayev, "Alcohol policy: world experience and Russian realities". Newsletter of the center for human demography and ecology of the Institute of economic forecasting RAS "Population and society", vol. 103, 2006. Retrieved from http://www.demoscope.ru/acrobat/ps103.pdf

[13] T. C. Schelling, Economic Analysis and Organized Crime. U. S. The President's Commission on Law Enforcement and Administration of Justice : Task Force Report : Organized Crime : Annotations and Consultants Paper, pp.114-126. Washington.

[14] O. A. Rozhkova, The history of the drink charges in the Russian Empire (Author's abstract dis. ... candidate Historical Sciences.) Retreated from ProQuest Dissertations and Theses database. 2007. http://www.dslib.net/istoria-otechestva/istorija-pitejnyh-sborov-vrossijskoj-imperii.html

[15] A. G. Bykova, Alcoholic question in the Russian Empire in the second half of XIX - early XX century. (Author's abstract dis. ... by Doctor Historical Sciences.) Retrieved from ProQuest Dissertations and Theses database. 2012. omgpu.ru/disser/download/autore.

[16] R. Y. Skokov, "Institutional development of addictive goods markets in modern Russia". Retrieved from, 2014 http://www.volgau.com/Portals/0/common/15/151023/skokov_ryu_mon ografiya_16032015.pdf?ver=2015-10-23-135625-650

[17] L. Popova, S .Popova, T.Dugina, D.Korobeynikov, O.Korobeynikova, "Cluster Policy in Agrarian Sphere in Implementation of Concept of Economic Growth". European Research Studies, XVIII, Issue 3, 2015. https://www.questia.com/library/journal/1G1-443990844/cluster-policyin-agrarian-sphere-in-implementation 